\title{
Continuity and renewal at the top: performance effects of the level, extent, type and frequency of top management team changes
}

Citation for published version (APA):

Olie, R. L., Glunk, U., \& Heijltjes, M. G. (2003). Continuity and renewal at the top: performance effects of the level, extent, type and frequency of top management team changes. METEOR, Maastricht University School of Business and Economics. METEOR Research Memorandum No. 049 https://doi.org/10.26481/umamet.2003049

Document status and date:

Published: 01/01/2003

DOI:

10.26481/umamet.2003049

Document Version:

Publisher's PDF, also known as Version of record

Please check the document version of this publication:

- A submitted manuscript is the version of the article upon submission and before peer-review. There can be important differences between the submitted version and the official published version of record.

People interested in the research are advised to contact the author for the final version of the publication, or visit the DOI to the publisher's website.

- The final author version and the galley proof are versions of the publication after peer review.

- The final published version features the final layout of the paper including the volume, issue and page numbers.

Link to publication

\footnotetext{
General rights rights.

- You may freely distribute the URL identifying the publication in the public portal. please follow below link for the End User Agreement:

www.umlib.nl/taverne-license

Take down policy

If you believe that this document breaches copyright please contact us at:

repository@maastrichtuniversity.nl

providing details and we will investigate your claim.
}

Copyright and moral rights for the publications made accessible in the public portal are retained by the authors and/or other copyright owners and it is a condition of accessing publications that users recognise and abide by the legal requirements associated with these

- Users may download and print one copy of any publication from the public portal for the purpose of private study or research.

- You may not further distribute the material or use it for any profit-making activity or commercial gain

If the publication is distributed under the terms of Article 25fa of the Dutch Copyright Act, indicated by the "Taverne" license above, 
CONTINUITY AND RENEWAL AT THE TOP:

PERFORMANCE EFFECTS OF THE LEVEL, EXTENT, TYPE AND

FREQUENCY OF TOP MANAGEMENT TEAM CHANGES

\author{
RENÉ OLIE \\ Erasmus University Rotterdam, Rotterdam School of Management/Faculteit \\ Bedrijfskunde, Department of Strategy and Business Environment, P.O.Box 1738, 3000 \\ DR Rotterdam, The Netherlands \\ Telephone: +31.10 .4082001$ \\ Telefax: +31.10 .4089013$ \\ E-mail: R.Olie@fbk.eur.nl
}

\title{
URSULA GLUNK
}

Universiteit Maastricht, Faculty of Economics and Business Administration, Organization Studies Group, P.O.Box 616, 6200 Maastricht, The Netherlands

Telephone: +31.43 .3883812$

Fax: +31.43 .3884877$

E-mail: $\underline{\text { U.Glunk@os.unimaas.nl }}$

\section{MARIËLLE G. HEIJLTJES}

Universiteit Maastricht, Faculty of Economics and Business Administration, Organization Studies Group, P.O.Box 616, 6200 Maastricht, The Netherlands Telephone: +31.43 .3883812$

Fax: +31.43 .3884877$

E-mail: $\underline{\text { M.Heijltjes@os.unimaas.nl }}$ 


\title{
CONTINUITY AND RENEWAL AT THE TOP: \\ PERFORMANCE EFFECTS OF THE LEVEL, EXTENT, TYPE AND \\ FREQUENCY OF TOP MANAGEMENT TEAM CHANGES
}

\begin{abstract}
This study examines performance effects of changes in the top management team using an eleven-year period longitudinal research design with a sample of 45 major Dutch multinationals. Since changes at the top are a multi-faceted phenomenon, we study the topic from four different angles. Results indicate that the level of change in terms of CEO versus non-CEO changes and the extent of change in terms of the proportion of managers entering or exiting the team do not influence subsequent firm performance. Type and frequency of change however do matter. Our results indicate that renewal of top management teams in terms of non-retirement exits and limited outside entries can be beneficial for firm performance in the following year, especially when exits and entries are well aligned. On the other hand, a certain degree of continuity is also warranted. Too many outside entries at the same time were found to be disadvantageous in the short-run, while many CEO successions in a row were found to be disadvantageous in the longerrun.
\end{abstract}




\section{INTRODUCTION}

Reaching the top of the corporate ladder may be difficult, but staying there seems to be an equal challenge. Approximately 40 of the 200 largest corporations in the US replaced their CEO in 2000 compared to 23 in 1999 (Leonard, 2001). A similar finding is reported by the second annual survey of CEO turnover by management consulting firm Booz Allen Hamilton, which indicates that CEO turnover in Europe and Asia continues to rise (Corporate Board, 2003). Also turnover of other top executives is known to be rather frequent. Empirical studies among large US firms reported executive turnover rates of more than 30\% during the late 1970s and mid 1980s (Jackson, Brett, Sessa, Cooper, Julin \& Peyronnin, 1991; Wagner, Pfeffer \& O'Reilly, 1984). A more recent study among Dutch multinational companies found comparably high figures for the late 1990s (Godthelp \& Glunk, 2003).

These results are intriguing since turnover at the top is an event of strategic and symbolic significance, for both internal and external stakeholders, as it can both symbolize and trigger fundamental changes in the strategic activities of a firm (Shen and Cannella, 2003; Hambrick and Mason, 1984; Pfeffer, 1981). In this context, top management turnover or replacement is an important mechanism to deal with organizational inertia (Tushman and Romanelli, 1985), to communicate a new strategic direction, and to adapt strategically to changing contexts (Wiersema and Bantel, 1993). At the same time, changes at the top are associated with dysfunctional discontinuities, short-terminism (DBM, 2002), disruption of social networks, established ways of working among remaining top managers, and growing turbulence at lower organizational levels (Shen and Canella, 2002; Krishnan, Miller and Judge, 1997; Tushman and 
Rosenkopf, 1996; Friedman and Saul, 1991). Finding a balance between continuity and renewal in top management teams is therefore an important organizational issue. This trade-off initiated the main research question that we are addressing in this paper: what are the performance effects of changes in the top management team?

Based on an eleven-year period longitudinal research design with a sample of 45 major Dutch multinationals, our paper contributes to the existing body of research in the following ways. First, in contrast to most researchers that have examined the performance effects of changes at the top (e.g., Beatty and Zajac, 1987; Leker and Salomo, 2000), we focus on the top team as the unit of analysis rather than on the CEO alone. With respect to the level of change we thus specifically consider CEO and non-CEO changes. Second, deviating from the tradition that $\mathrm{CEO}$ or other team changes imply succession events (e.g., Shen and Cannella, 2002), we define team changes in terms of two separate events that are not necessarily related: entries and exits. We investigate their separate as well as their combined effect on subsequent performance. Third, we analyze the type of change by studying characteristics of entering members - in terms of insider/outsider status - and exiting members- in terms of retirement (voluntary) or non-retirement (involuntary) departure. This allows us to examine whether specific types of entries and exits influence the dynamics in the top team and subsequent performance in different ways. Finally, our longitudinal research design enables the analysis of the effects of change frequency per firm over time. 


\section{CHANGES IN THE TOP TEAM}

Changes in the top team are a widely explored topic (Kesner and Sebora, 1994). Studies in this area have addressed topics ranging from antecedent conditions of $\mathrm{CEO} /$ team change to types of $\mathrm{CEO} /$ team changes, intermediate team processes and performance effects. In order to provide some structure into this vast body of literature and to be able to place our study into perspective, an illustrative overview of some of the relationships studied is provided in Figure 1. Our study focuses on the financial performance effects of top team changes, thereby zooming in on the link between 'CEO/top team changes' and 'outcomes.'

-Insert Figure 1 about here-

A principal issue when addressing the link between top management change and performance, is the question to what extent top management really matters. Here deterministic and voluntaristic viewpoints can be distinguished. According to the deterministic viewpoint, top management has no or limited effect on organizational outcomes including performance. Firm performance is principally a result of factors such as market conditions over which management has little control. This viewpoint is most strongly represented in the population ecology approach (Hannan and Freeman, 1977, 1989) claiming that organizations are subject to inertial forces. As such managerial changes at the top of the organization are believed to have no or limited effects on firm performance (Fizel and D'Itri, 1997). Even though management is assumed to have little effect, top management is generally held accountable by the firm's stakeholders. This 
implies that poor and good firm performance is attributed to top management's decisions and actions irrespective of its effects (Pfeffer, 1977). Changing top-level management therefore is a strongly ritualistic, symbolic act particularly in the case of poor performance.

By contrast, the voluntaristic perspective, also known as the 'strategic choice' perspective (Child, 1972) takes the opposite view assuming that organizational leaders are directly responsible for organizational outcomes. This view is widely shared and underlies much theorizing in strategic management and other organizational fields (Pfeffer, 1982), including the impact of individual leaders (Meindl, Ehrlich and Dukerich, 1985).

The theoretical framework guiding the development of hypotheses in this paper is rooted in the voluntaristic perspective. Spcifically, the view of the 'upper-echelon perspective' (Hambrick and Mason, 1984) and the more comprehensive perspective of strategic leadership theory (Cannella and Monroe, 1997) is adopted, combined with insights from succession research. Based on Cyert and March's (1963) concept of 'dominant coalition', strategic leadership theory argues that leadership principally is a shared activity. Studying the whole group of top-level managers who are responsible for selecting and implementing the firm's strategies, therefore provides better predictions of organizational outcomes than the individual characteristics of a single CEO. Quite some empirical studies have supported the validity of this argument (Tushman, Virany and Romanelli, 1985; Bantel and Jackson, 1989; Goodstein, Gautam and Boeker, 1994; Wiersema and Bantel, 1992; Boeker 1992). While these studies demonstrate the added 
value of the team focus, most of them approach team changes as a consequence of CEO succession rather than as a phenomenon in its own right.

\section{RESEARCH MODEL AND HYPOTHESES}

This study differs from many other executive turnover/change studies in that it takes the whole team as the unit of analysis. In doing so, we consider four aspects of top team changes. The first aspect is the level of change and explores the performance effects of CEO and non-CEO changes. The second aspect is the extent of team changes and explores the effects of minor and major changes in team composition on performance. The third aspect, type of change, considers the nature of these changes. Here, we analyze the effects of team exits and entries on performance. Apart from their overall effect, we also consider two types of team entries, i.e., insider and outsider entries, and two types of exits, i.e. retirement (voluntary) and non-retirement (involuntary) exits. Finally, we track the performance effects of frequent and infrequent team changes over time. Figure 2 summarizes our research model.

-Insert Figure 2 about here

\section{Level of change: CEO versus non-CEO effects}

As the individual who has ultimate legal authority and responsibility in today's corporate hierarchy (Vancil, 1987; Kesner and Sebora, 1994: 328), the CEO has been the obvious topic of interest in most studies. The underlying rationale is that a new CEO can be instrumental in breaking established modes of operating or organizational routines 
(Hannan and Freeman, 1984; Nelson and Winter, 1982) by initiating a new strategic direction and thereby improving performance (Andrews, 2001; Gordon et al., 2000; Kesner and Dalton, 1994). Empirical findings on performance effects of CEO succession have been inconclusive, however, leading to the proposition that merely changing a single leader or CEO is unlikely to automatically lead to performance improvements. Since in large, complex organizations CEOs are an integral part of a team, CEO change and top management change should not be regarded in isolation (Virany et al., 1992; Shen and Cannella, 2002). Furthermore, team changes are important levers for organizational adaptation (Virany et al., 1992; Tushman and Rosenkopf, 1997). CEO changes by themselves may not introduce sufficient new and diverse experience or knowledge to alter established understandings and entrenched activity patterns. Moreover, without the commitment of incumbent team members new CEOs will be unable to implement new changes (Virany et al., 1992). Thus in this view, it is assumed that CEO changes are only effective when combined with changes in the wider top management team. For example, Virany et al. (1992) and Tushman and Rosenkopf (1997) found that executive team changes had significant effects on organization outcomes in both stable and turbulent contexts. As Tushman and Rosenkopf (1996: 950) state: 'These results indicate that executive team changes have more profound effects on organization outcomes than simple CEO succession'. Moreover in both studies it appeared that executive team changes alone (i.e. irrespective of CEO changes) were sufficient to affect organizational performance. On basis of these arguments and research findings we state the following hypothesis: 
Hypothesis 1a: CEO changes by themselves have no significant impact on subsequent performance.

Hypothesis $1 b$ : Non-CEO changes in top management teams have a significant impact on subsequent performance.

Hypothesis 1c: $\mathrm{CEO}$ changes combined with non-CEO changes in top management teams have a significant impact on subsequent performance.

\section{Extent of change in the top team}

Where in the previous section the focus was on the distinction between CEO and nonCEO changes, this section focuses on the extent of change in the top team as a whole (including the CEO). In addition to the notion that organizational leadership is a shared activity, the strategic leadership perspective emphasizes that understanding the background, experiences, and values of top managers is of central importance in explaining the choices they make. As changes at the top effectively change the composition of the teams, for example in terms of social and functional background or personality, this may have both positive and negative effects. The positive effects are linked to the diversity of perspectives. Newcomers are believed to introduce new perspectives, to break down persistence with prior strategies (Nystrom and Starbuck, 1984) and to introduce strategic change (Gordon et al., 2000). These positive effects may be particularly beneficial in more rapidly changing environments. Consistent with this idea, Virany et al. (1992) found a positive effect for team turnover on organizational performance in turbulent industries. 
While sweeping team changes may have beneficial effects under conditions of turbulence and for firms in need of strategic reorientation, convergent patterns of adaptation seem more common than episodes of revolutionary change (Gordon et al., 2000; Lant et al., 1992; Amburgey, Kelly and Barnett, 1993). In this regard, the social costs involved with changes in management become important. These costs are principally related to the process of team integration. New members tend to increase the cognitive diversity in teams, but they may also lead to a disruption of effective activity patterns (Grusky, 1963), friction and dysfunctional dissensus among team members, slowness in strategic decision- making and action (Finkelstein and Hambrick, 1996; Hambrick, Cho and Chen, 1996) and thus hamper organizational performance (Iaquinto and Fredrickson, 1997). As a consequence in this case, large-scale turnover in the top management team will have a negative effect on performance (Tushman and Rosenkopf, 1996). Further support for the potentially negative effects of many team changes comes from research on strategic change. For example, a study by Gordon et al. (2000) indicates that instead of yielding positive results in terms of increasing the likelihood of strategic reorientation and increasing the viability of the organization, top team turnover had a negative effect. As the authors state, it takes time for a new team to build trust and achieve consensus before implementing change. Top team turnover may dampen efforts for rapid strategic change (Gordon et al., 2000: 919). 
Overall, we may conclude that the extent of change in the top of the organization can have important implications for organizational performance. However, the direction of these effects is ambiguous. Therefore, we state the following general hypothesis.

Hypothesis 2: The extent of change in the top team as a whole has a significant effect on subsequent performance.

\section{Type of change: the effects of entries and exists}

After having discussed the level and extent of change, this section discusses the type of change in terms of entries and exits. Most research on CEO/team changes has studied succession events without distinguishing between entries and exits. These studies assume that the two events are perfectly related in the sense that leaving executives will directly be replaced by new team members. However, with the exception of the CEO, top management team members can also leave without immediately being replaced. Top management teams thus expand and contract over time as a result of the restructuring of businesses, merger and acquisitions, or other strategic reorientations. For example, companies may incorporate top managers from acquired companies in their TMT in order to coopt their services and to smoothen the transition process (Cannella and Hambrick, 1993; Hambrick and Cannella, 1993). Alternatively, diversified firms may reduce their top management size and decide not to replace retiring executives when it refocuses on core activities. In brief, departure does not necessarily mean replacement; entry does not automatically imply succession. Hence, exit and entry change the composition and size of the top management team but not always for the same reasons. From this perspective, it seems important to disentangle the two events. 
An even more important reason in light of our focus on performance effects of team changes is that exits and entries may have different implications. New members bring in new perspectives, and may help to counter forces of inertia (Gordon et al., 2000). At the same time it will take time for new members to become effective as they must gain familiarity in their new roles and establish networks of contacts to accomplish activities (Kotter, 1982). By contrast, exits imply the loss of firm-specific, and often nontransferable knowledge (Kotter, 1982). On the other hand, exits of individual members may also imply the 'cutting of dead wood', or of people who have grown 'stale in the saddle' and, as such, represent impediments to effective team processes and change (Michel and Hambrick, 1991; Miller, 1991). Hence, entries and exits may both have positive and negative effects.

In a succession study of the cement industry Tushman and Rosenkopf (1996) found that executive team exits and entries indeed have different impacts on subsequent organizational performance. When controlling for environmental turbulence, executive team entries were negatively related with subsequent firm performance, while senior team exits were positively associated with performance. Except for this study, no other study that we know of has explored the effects of both exits and entries at team level in relation to company performance. Research on executive succession has typically focused on the effects of CEO entry alone, or in combination with executive team exits (the latter usually perceived as a consequence of the former). As we examine firms in a wide variety of industries in the present study, we expect a general effect of team entries and exits. Hence, we state: 
Hypothesis 3a: Team entries and exits have a different effect on subsequent performance.

Furthermore, we assume that in general a good coupling of executive exits and entries will be advantageous for firm performance. The hiring of new executives without others leaving is likely to disrupt team functioning as power struggles might occur. Exits without new entries or with delayed entries, on the other hand, can be harmful for continuity and the division of responsibilities. Assuming that a balanced executive succession is better for team functioning than uncoupled changes, we thus state:

Hypothesis 3b: The better the alignment of entries and exits, the better subsequent performance.

\section{Type of change: the effects of insider and outsider entries}

When examining the type of entry in more detail, it appears that the one characteristic that has received most attention from scholars is the origin of the new entrant. In particular the question as to whether he or she comes from inside or outside the company (Kesner and Sebora, 1994: 330). Most studies (e.g. Zajac, 1990; Virany et al., 1992; Shen and Cannella, 2002) find that firms with insider CEOs tend to be significantly more profitable than firms with outsider CEOs. One reason is that information asymmetries between the Board and outside candidates about the characteristics of the CEO create adverse selection problems (Zajac, 1990). As a result, "a Board's decision to hire an outside CEO will be, on average, a worse decision (in terms of performance implications) than a Board's decision to hire an insider CEO" (Zajac, 1990:220). Another explanation is that externally recruited managers lack the social and political network inside the 
organization, and knowledge of the organizational systems (Virany et al., 1992; Shen and Cannella, 2002). As a result they may have difficulty implementing change.

So far, the effect of insider/outsider selection on subsequent performance has not been researched at the team level. But, also in this context we may expect to find this distinction to be relevant. For example, new members working for the same company for a long period can be relatively familiar with the existing group of top managers. In addition, long organizational tenure increases cohesion (Finkelstein and Hambrick, 1996). New and old members share similar firm-specific experiences, which facilitate communication and provide a strong binding factor (Finkelstein and Hambrick, 1996). Thus, we expect:

Hypothesis 4: Outside entries have a more negative effect on subsequent performance than entries of insiders.

\section{Type of change: the effects of voluntary and involuntary exits}

When analyzing the type of exit in more detail, it is valuable to distinguish between voluntary and involuntary exits. In doing so, two opposing points of view emerge. From an internal monitoring perspective, one expects that poorly performing managers are removed from their functions. The resulting involuntary exit of a top manager should then lead to improvements in the performance of the organization due to actions taken by the firm to 'clean up'. Most studies that address the voluntary or involuntary nature of exits from this perspective focus on the CEO, an exception is a study by Denis and Denis (1995). They find that involuntary, forced departures of top managers are followed by 
significant improvements in operating performance while retirements (voluntary departures) are followed by smaller increases in performance.

Another line of reasoning with respect to performance effects yields quite the opposite result. When a member of the top team leaves the team this will upset the status quo and thus result in a decline rather than an increase in performance. Furthermore, if the assumption is made that the more unexpected and sudden the exit occurs, the more disruptive the event will be for the social infrastructure (Vancil, 1987; Grusky, 1963), one can argue that involuntary exits have a more negative effect on firm performance than voluntary exits. The reasoning being that voluntary exits (e.g., retirements) can be carefully prepared and planned thereby limiting damage to the way of operating of the remainder of the team. Our hypothesis thus consists of the following two competing statements.

Hypothesis 5a: Involuntary exits have a more positive effect on subsequent performance than voluntary exits.

Hypothesis 5b: Involuntary exits have a more negative effect on subsequent performance than voluntary exits.

\section{Performance effects of the frequency of changes over time}

The previous hypotheses dealt with the effect of discrete turnover events on subsequent performance. In the following, we will consider effects of turnover frequency in top teams over a period of time. 
The frequency of exits and entries in a top team is closely linked to team tenure, as high turnover frequency automatically implies low average team tenure, and vice versa. Research on the effects of team tenure generally suggests that long average team tenure (or a low turnover frequency) is negatively associated with organizational change and innovativeness (Finkelstein and Hambrick, 1996). Longer tenured executives are more devoted to the maintenance of the status quo than shorter tenured executives (Hambrick, Geletkanycz and Frederickson, 1993). The likelihood that individual members will challenge the status quo is reduced in long-tenured top management teams (Michel and Hambrick, 1992).

However, short average team tenure (or high turnover frequency) may have equally undesirable outcomes. For example, it has been suggested that it takes up to two years for a new CEO to fully take charge in a new job (Gabarro, 1987; Vancil, 1987). Shorter tenures therefore imply that top managers have less time to implement meaningful changes and short-term effects become the overriding concern, which threatens the long-term viability of the organization (DBM, 2002). In addition, short tenures may lead to several social costs for the team, as we have stated before. In order to integrate socially and to develop effective communication patterns, a certain degree of stability in team membership is required (Wiersema and Bantel, 1992). Finally, the frequent replacement of top management team members, including the CEO, will have a negative effect on the image of reliability and accountability of the firm (Hannan and Freeman, 1984; Friedman and Saul, 1991).

Virany et al. (1992) found that consistently high-performing organizations were moderate in their use of CEO and executive team changes. These organizations typically 
took a more proactive approach with regard to $\mathrm{CEO}$ and team renewal than moderately performing companies. While the latter group of companies tended to initiate changes in response to declining performance, the group of high-performing organizations timed their successions in anticipation of environmental changes. Low-performing or failing organizations in this study either initiated no executive change, or initiated excessive team changes repeatedly over successive years (between $40-100 \%$ turnover). Both strategies resulted in further decline. A similar finding is reported in the study by Hambrick and D'Aveni (1992) on corporate bankruptcies. As opposed to survivor firms, the top management teams of failing firms were characterized by differing tenure characteristics. Some teams were very homogeneous in the sense that they were longstanding, or had undergone a wholesale team replacement. In other teams there were schismatic combinations of very long-tenured and very short-tenured members.

Concluding, some degree of turnover seems beneficial in order to introduce sufficient new and diverse experience or knowledge and to alter established understandings and entrenched activity patterns. However, high rates of turnover make it impossible to absorb the changes and to develop stable relationships within the team and with outside parties. Thus, it seems that a medium degree of renewal is to be preferred over sustained stability or radical and frequent change. Consequently, we state the following hypothesis:

Hypothesis 6: There is an inverted u-shaped relationship between frequency of changes in the top team and performance over time. 


\section{METHODS}

\section{Sample and Data Collection}

Hypotheses were tested with longitudinal data that cover 11 years of observations ranging from 1990 to 2000. Our sample comprises the 45 largest MNCs in the Netherlands. Starting from the top 50 firms on the Amsterdam Stock Exchange (in terms of total revenues of 1996), we excluded three bi-national firms (i.e., Shell, Unilever, Fortis), one Belgium firm (i.e., EVC) and one firm with insufficient data, from our sample in order to increase the accuracy of analysis. The resulting 45 companies in our sample operate in various industries, including among others chemicals, publishing \& printing, insurances,

construction, and transportation. Their average sales during the observation period were 4.3 billion $€$ with 29,000 employees. Since the resulting sample comprises the 45 largest listed firms and it is thus not randomly chosen, the sample is not representative of all 165 firms listed on the Amsterdam Stock Exchange.

\section{Dependent Measures}

Firm Performance. Firm performance was assessed in terms of yearly return on assets (ROA), which is a widely used performance measure in CEO turnover and succession research (Gordon et al., 2002; Guthrie and Datta, 1998; Kesner and Dalton, 1994; Shen \& Cannella, 2002; Tushman \& Rosenkopf, 1996; Virany et al., 1992; Puffer and Weintrop, 1991; Zajac, 1990). 
In order to test Hypotheses 1-5, we determined the relative change in ROA following the TMT changes by subtracting ROA in t0 (when the change took place) from ROA in $\mathrm{t}+\mathrm{x}$ (see also Tushman \& Rosenkopf, 1996; Virany et al., 1992 for a similar procedure used). Though change in ROA is known to be more difficult to predict than absolute ROA, this measure makes it possible to benchmark post-change performance against performance at the time the executive change occurred. While prior studies have studied the effects of top management team changes two years after the event (Tushman \& Rosenkopf, 1996; Virany et al., 1992), we measured the relative change in ROA one, two, and three years after the event. Such a wider post-change performance horizon allows us to assess the robustness of the findings over time.

For testing Hypothesis 6 we determined the average level of ROA over a two-year time period. As we aimed at testing performance effects of change frequency, we had to make sure that the measurement of performance did not overlap in time with the measurement of the independent variable to avoid a reversal of causal order. We used the two years of our time window (1999-2000) to determine average ROA and measured the frequency of changes in the preceding nine years (1990-1998).

\section{Independent Measures}

The Dutch corporate governance structure is based on a two-tier system in which the Management Board and the Supervisory Board are separate entities. As the present study examines changes at the top management team level, our data collection focused exclusively on the Management Board. 
Level of change: CEO vs. non-CEO. For measuring changes in the top management team we recorded all leaving or entering executives per year by distinguishing between CEOs and non-CEOs. A dummy variable indicated per year and firm whether or not a CEO change had taken place. Change of non-CEOs was calculated by counting the sum of non-CEO entries and exits per year and dividing it by the size of the team in that year (see Tushman and Rosenkopf, 1996; Virany et al.,1992).

Extent of change. We determined the proportion of change per year and company by dividing the number of changes per year (CEO and non-CEO combined) by the total number of top management team members at the beginning of that year (proportion of change). It should be noted that these changes include both, exits and entries.

Type of change: exits vs. entries. Next to the general extent of change, entries and exits were considered independently as not every entry automatically leads to an exit or vice versa. For each team, we recorded the number of exit and entry events per year and calculated entry and exit proportions per year and company by dividing the number of exits (or entries) per year by the total number of top management team members at the beginning of that year (proportion of exits, proportion of entries).

Type of entries: insiders vs. outsiders. Previous research has applied varying degrees of rigor for defining newcomers to the top management team as insiders or outsiders. Some studies define top managers as outsiders when they have less than two years (Cannella and Lubatkin, 1993) or less than five years of organizational tenure (Chaganti and Sambharya, 1987; Datta and Guthrie, 1994; Guthrie and Datta, 1998). We follow the definition of Dalton and Kesner $(1985,1983)$ and define an outsider as being a top manager who did not work for the organization before the appointment to the board. 
As sometimes within a single company several new entries take place per year, we coded entry events as outside entries only, if all entering executives had an organizational tenure of zero. The resulting insider/outsider variable is binary, with insiders coded as ' 0 ' and outsiders coded as ' 1 '. We also used organizational tenure of new entries as a continuous variable in order to validate the insider-outsider analyses.

Type of exits: voluntary vs. involuntary. It is not easy to determine whether exits at the top level are voluntary or not without first-hand information from people who were part of the team. In order to be able to take this variable into account, we used an approximation that considers exits due to retirement age as planned and thus voluntary and all other exits as involuntary. We have to admit that the definition of latter category is rough, as it comprises dismissals as well as resignations. We nevertheless assume that this category is different from retirement exits, as dismissals as well as resignations imply that at least one of the parties involved judges the employment relationship as not fully satisfactory (Schneider, 1987).

Retirement age in the Netherlands is 65 ; quite some people, however, already quit work at the age of 60 . We thus defined all exits of executives who were 60 or older as retirements (voluntary exits, coded as "1"), all other exits were considered as nonretirement (involuntary) and coded as " 0 ". If several people left the team in the same year, these exits were only counted as retirements if all were above 60 .

Frequency of change. In order to test Hypothesis 6, we measured the frequency of change over a nine-year period (1990-1998) and linked it to subsequent performance (1999-2000). We counted per firm the number of years with changes in the top 
management team. Additionally, we distinguished between CEO and non-CEO changes. We did not distinguish between exits and entries as they often happen in the same year.

\section{Control Variables}

A number of control variables were included in the current study. We added a dummy variable distinguishing between non-manufacturing (coded as 0 ) and manufacturing firms (coded as 1) in order to have a rough sector control in our multi-industry sample. We controlled for firm size by using the natural logarithmic transformation of net sales in $€$ per firm and year as firm size may influence both, changes in the top management team and performance. Furthermore, we controlled for firm performance prior to the entry or exit events, as performance effects might be different for firms with higher or lower performance rates prior to the executive change (Kesner and Dalton, 1994; Murphy and Zimmerman, 1993). In order to capture such effects, we measured ROA change prior to the top management team change by subtracting ROA at the end of $t-1$ from ROA $t-2$. Finally, for testing Hypotheses 2-5 that concern changes in the team as a whole (CEO and non-CEOs) we also controlled for the fact whether or not a CEO succession had taken place in a given year. For testing Hypotheses 4 and 5 we also controlled for the proportion of exits and entries in a given year.

\section{Analysis}

Hypotheses 1-5 were analyzed by using random-effect regression models in a pooled cross-sectional time series (see Greene, 2003). We analyzed 495 year-firm observations where the data set contains a separate entry for each firm $(\mathrm{N}=45)$ and year $(\mathrm{N}=11)$. It 
should be noted that the number of year-firm observations is not identical for the different time-dependent performance measures. Taking the control variable 'prior performance change' into account, we can link the dependent variable ROA change in $t+1$ to entries or exits between 1992 and $1999(\mathrm{~N}=360)$, ROA change in $\mathrm{t}+2$ to entries/exits between 1992 and $1998(\mathrm{~N}=315)$, and ROA change in $\mathrm{t}+3$ to entries/exits between 1992 and 1997 $(\mathrm{N}=270)$. It should also be noted that due to some missing data in the 11-year period, we do not have complete information for all year-firm observations. We lack performance data for 22 cases, insider/outsider data for 28 cases, and retirement data for 42 cases. Hypothesis 6 was tested with a standard OLS regression over 45 firms and linked the frequency of change 1990-1998 to average performance 1999-2000.

\section{RESULTS}

In total, 425 executives populated the top management teams of the 45 firms we studied between 1990 and 2000. Of the 170 top executives who were board members in 1990, only 44 were still in function in 2000. During our 11-year observation period, 227 exits (yearly average for the 45 firms: 20.6) and 250 entries (yearly average: 22.7 ) took place. Some firms had entries or exits of several executives per year. The maximum number of exits as well as entries per year and firm was 5 . On average, the top management teams had 4.2 members, ranging from 2 to 13 . The average team size slightly increased from 1990 (4 members) to 2000 (4.5 members). Overall, the yearly percentage of exits increased considerably between 1990 and 2000. While in 1990 only $8 \%$ of the executives left the boards, the percentage of exits in 1999 was $13 \%$, in 2000 even $35 \%$. In the same 
period, the percentage of entries did not change as drastically, increasing only from $11 \%$ to $15 \%$.

-Insert Table 1 about here-

Table 1 reports the means, standard deviations, and correlation coefficients of the variables used for testing hypotheses 1-5. The correlation coefficients show that larger firms (in terms of sales) tend to have more executive changes. Moreover, we see that a decrease in ROA in t-1 (prior performance) leads to higher proportions of executive change in t0 and to a performance increase in the following three years. Concerning our independent variables, only the proportion of exits within the whole team is positively linked to subsequent performance.

Table 2 shows the results of testing Hypotheses 1 and 2. Concerning the control variables, only ROA change prior to executive changes was found to significantly influence subsequent ROA change. The negative sign of this relationship indicates that an increase in ROA in one year does in general lead to a decrease in the following year and vice versa. Overall, it should be noted that the variance explained by the models is rather low, which however is rather common when predicting performance changes.

-Insert Table 2 about here

Hypotheses 1a-c distinguished between CEO and non-CEO changes. Within the 45 firms studied, 69 CEO successions took place between 1990-2000. At the same time, we 
observed changes of one or more non-CEOs in 210 out of the 495 year-firm observations. Hypothesis 1a assumed that CEO changes have no independent effects on subsequent performance. This hypothesis was supported. Hypothesis $1 \mathrm{~b}$ however, which assumed a significant effect of non-CEO changes, could not be confirmed. Neither CEO changes nor non-CEO changes were found to increase or decrease ROA in the following three years (Models 1-3). Also the interaction effect that was proposed by Hypothesis 1c could not be confirmed (Models 4-6). So, whether or not CEO succession is accompanied by turnover of other team members does not matter for subsequent changes in ROA.

Hypothesis 2 suggested that it is the extent of change in the whole team (including CEO and non-CEO members) that will have effects on subsequent performance. Our data, however, do not support this hypothesis. The overall number of executive changes relative to the team size was not found to have any effects on subsequent performance (Models 7-9).

Hypothesis 3a distinguished between two types of changes, exits and entries, which were assumed to have different effects on subsequent performance. Our results confirm this hypothesis for ROA change in $\mathrm{t} 1$ and $\mathrm{t} 2$. Higher proportions of exits were found to lead to an increase in ROA one and two years later. At the same time, the proportion of entries is negatively, yet insignificantly, linked to subsequent performance (Table 3, Models 1-3). Concerning ROA change in t3, we see again that exits and entries have opposing signs, here however, neither effect is significant. For testing Hypothesis $3 b$, we analyzed the interaction between exit and entry proportions. For ROA in t1, we found a significantly positive effect, indicating that the better exits and entries are aligned 
the more ROA increases in the following year (Table 3, Models 4-6). Hypothesis $3 \mathrm{~b}$ was thus confirmed for ROA change in $\mathrm{t} 1$.

-Insert Table 3 about here-

Table 4 shows the results concerning Hypotheses 4 and 5 dealing with specific types of exits and entries. Hypothesis 4 assumed that entries of outsiders have more negative effects on subsequent performance than entries of insiders. Our results show that things are somewhat more complex. Overall, the hiring of new executive team members from outside the firm is more advantageous for an increase in ROA in the following year than the hiring of insiders. However, when many entries take place, the hiring of outsiders shows negative effects (Table 4, Models 1-3). No performance effects were found two and three years following the entries. When using organizational tenure of new entrants as a continuous variable the above-mentioned results were confirmed. Lower organizational tenure leads to an increase in ROA in the following year, yet with a higher entry proportion, low organizational tenure of new entrants becomes disadvantageous. Overall, we can conclude that Hypothesis 4 could not be confirmed, as outside entries were not found to have more negative effects than inside entries. Only when teams do hire several new executives at the same time (higher entry proportion), is the hiring of outsiders disadvantageous.

Hypotheses $5 \mathrm{a}$ and $\mathrm{b}$ were formulated in opposing ways and compared the effects of retirement and non-retirement exits. Here, we find that in general exits due to retirement (voluntary exits) lead to a decrease in ROA in the subsequent year (Table 4, 
Models 3). This supports Hypothesis 5a, which stated that non-retirement exits have more positive effects than retirement exits. No performance effects were found two and three years following the exits. Also, whether more or less executives leave the team due to retirement has no effect (Table 4, Models 4-6).

-Insert Table 4 about here-

Hypothesis 6 assumed an inverted u-shaped relationship between the frequency of changes in a team over time and performance. In our nine-year observation period, the number of years with executive changes was normally distributed among the 45 firms in our sample, ranging from 0 to 8 years. CEO changes were less frequent. One third of the firms experienced no CEO succession at all, one third experienced one succession another third had two or three successions. Table 5 shows the means, standard deviations and correlations of the variables under study. Here we see that in general large firms (in terms of sales) have more executive changes yet realize lower returns on assets. A high frequency of changes in the top management team over a longer period of time seems to have rather negative effects on ROA, especially when it concerns CEO changes.

Insert Table 5 about here-

Table 6 reports the results of the OLS regression analysis within our sample of 45 firms. regression analyses. The expected inverted u-shape relationship between executive change and performance could not be found (Model 2). Here, we have to note that the 
intercorrelation between the change variable and its squared term is very high (.95) and might distort the results. Nevertheless, with an inverted u-shaped relationship we would expect that the signs of their coefficients point in the opposite direction. What we did find is that a high frequency of $\mathrm{CEO}$ changes has a marginally significant negative effect on performance, while a high frequency of non-CEO changes does not matter (Models 3 and 4). Adding a squared term of these variables did not improve the models.

------------Insert Table 6 about here--------------

\section{DISCUSSION AND CONCLUSION}

Drawing upon insights from strategic leadership theory and more specifically the upperechelon perspective, this paper studied performance effects of changes in the top management team. Unlike previous studies, we focused on the whole team rather than just on CEOs and distinguished between level, extent, type, and frequency of changes. In this way, we were able to study the phenomenon of continuity or renewal at the top from different angles and with varying degrees of specificity.

Overall, this approach proved to be useful as with increasing specificity, the performance effects of changes became more pronounced. When looking at our findings with regard to the first two hypotheses (level and extent), one might come to the conclusion that the deterministic viewpoint holds: it does not matter for firm performance whether or not a change takes place in the executive team. Unlike Virany et al. (1992) and Tushman and Rosenkopf (1996) we found neither CEO nor non-CEO changes to 
have any impact on performance. Also, the overall extent of change in a team within a given year showed no significant performance effects.

However, as soon as the type of executive change was further specified, the picture changed. In line Tushman \& Rosenkopf (1996), we found executive exits to be more advantageous than executive entries. We found that exits, and especially nonretirement exits have positive performance effects. This can be explained by the fact that a non-retirement exit is typically preceded by a certain level of dissatisfaction with the employment relationship, either on the side of the employer (in case of dismissal) or the side of the executive (in case of resignation). Such dissatisfaction is likely to result from a lack of fit between the leaving executive and the rest of the team (e.g., Jackson et al., 1991; Wagner et al., 1984). Assuming that the departure of these executives in beneficial for team homogeneity and functioning, it is not surprising to find positive performance effects associated with it. Retirement exits do follow a different dynamic. Our results show that they are negatively linked to performance. Here, senior team members with firm-specific knowledge and experience leave the team (Kotter, 1982). Although these departures are usually planned, our results show that the negative effects of such a loss can obviously not immediately be compensated.

Executive entries were in general not linked with performance. This, however, also changed under certain conditions. Entries showed positive performance effects when closely aligned with exits or when it concerned outside entries. Larger numbers of outside entries at the same time, however, led to a decrease in performance. The generally positive effects of outside entries might be explained by the fact that outsiders bring in new perspectives and can help to counter forces of inertia (Cannella \& Lubatkin, 1993; 
Finkelstein \& Hambrick, 1996; Gordon et al., 2000). Many entries of outsiders, however, increase socialization costs (Datta \& Guthrie, 1998) and change the character of the team to such an extent that its functioning becomes disrupted. Interestingly, CEO research typically finds inside successors to lead to better performance (Zajac, 1990; Virany et al., 1992; Shen and Cannella, 2002). Unfortunately, the numbers of CEO successions in the current sample was too limited for analyzing potential differences in outside entries at the CEO and non-CEO level. Our results combined with findings from succession research seem to indicate that outside entries are only advantageous when non-CEOs are concerned. A possible explanation might be that compared with CEOs, non-CEOs depend less on firm-specific knowledge and an established network of contacts to accomplish their task successfully.

At this point, it might be important to focus on the two different time perspectives we employed. In the first set of analyses (concerning level, extent, and type of change) we considered discrete changes per year and firm and linked them to performance in the three following years. The performance effects we were talking about in the previous paragraphs concern mainly short-term effects. Except for executive exits, we found no performance effects that lasted longer than one year following the change. This might be explained by the fact that additional changes might take place that then overlap the effects of the previous ones.

In the last analysis, we focused on potential cumulative effects of changes over a longer period of time. While the level of change (CEO vs. non-CEO) did show no distinctive performance effect in our yearly analysis, this aspect became important when studying the frequency of change over time. We found that firms with executive changes 
in several consecutive years did not perform any different from firms with fewer or no changes in the same period. However, firms with up to three CEO changes in a nine-year period, performed worse than firms with fewer or no such changes.

Overall, the paper showed that next to CEO succession research, it is useful to also study changes in the top management team as a whole. We hope that our framework provided some guidance of how to deal with the additional complexities involved. Our results indicated that renewal of top management teams in terms of non-retirement exits and limited outside entries can be beneficial for firm performance in the following year, especially when exits and entries are well aligned. On the other hand, a certain degree of continuity is also warranted. Too many outside entries at the same time were found to be disadvantageous in the short-run, while many CEO successions in a row were found to be disadvantageous in the longer-run.

\section{Limitations of the current study and suggestions for future research}

This study is an initial step in investigating the effects of changes at the team level on performance. Further research is needed to provide insight into the complex effects of team changes in different organizational contexts. For example, in the present study we examined the performance effects of team changes based on a set of companies originating from a variety of industries. As companies in different organizational contexts may exhibit different turnover patterns as a result of the turbulence they face in their environments, this can be considered as an important limitation of this study. For example, the studies by Tushman and Rosenkopf (1996) of the cement industry and Virany et al. (1992) of the minicomputer industry suggest that incremental change of top 
management is positively associated with organizational performance in stable contexts but less so in turbulent contexts.

A further limitation is the use of retirement versus non-retirement as a proxy for voluntary or involuntary turnover. Although widely used, a more subtle measure is needed to fully capture the reasons behind a particular turnover event. Researchers face significant difficulties in distinguishing voluntary from involuntary resignations as companies seldom are fully open about the true reasons behind turnover (Denis and Denis, 1995; Shen and Canella, 2002; Leeker and Salomo, 2000). A more fine-grained measure, for example between 'unavoidable change' (retirement), 'voluntary dismissal' (resignation) and 'involuntary dismissal' (dismissal) (c.f., Leeker and Salomo, 2000), could thus be helpful.

Similar concerns may be raised against our operationalization of the insider/outsider construct measured by the number of years new entrants worked with the firm before they entered the top management team. We used a dichotomized categorization as well as a continuous definition of insider-/outsidership, both based on organizational tenure of new entrants. However, finer and alternative distinctions of the insidership can be thought of. One relevant category is the contrast between intra-firm, intra-industry and outside-industry successions (Zhang and Rajogopalan, 2003). Yet, also non-tenure related measures may be considered. New members can be relatively similar to incumbent members in terms of firm-specific experiences and skills, but may be different in other important fields such as gender, race or functional background. Evidence suggests that such differences can be equally significant in influencing team dynamics (c.f., Wagner et al, 1984; Jackson et al., 1991). 
A final limitation of the study, which may be considered a strength at the same time, is related to the national identity of our sample. Most turnover studies are based on US samples. This applies to succession studies in general and to upper echelon studies in particular. To our knowledge, research on team changes involving non-US companies is practically nonexistent. As a result, the national context of strategic leadership is largely ignored as a potentially important determinant of top management change and outcomes (Olie and Van Iterson, 2003). For example, team-based philosophies may be more consistent with some cultures than others (Kirkman and Shapiro, 1997). These attitudes may have important implications for the team dynamics that we have described in this paper. Similarly, leadership structures tend to vary across countries as a result of cultural values (Hofstede, 2002) as well as institutional context (Olie and Van Iterson, 2003). These differences may hold significant implications for the effects of top management team changes on performance. These are all issues that can be taken up for further research. 


\section{REFERENCES}

Allgood, S., \& Farrell, K.A. 2000. The effect of CEO tenure on the relation between firm performance and turnover. The Journal of Financial Research: 23: 373-390.

Amburgey, T.L., Kelly, D., \& Barnett, W.P. 1993. Resetting the clock: The dynamics of organizational change and failure. Administrative Science Quarterly, 38: 61-73.

Andrews, K.Z. 2001. The performance impact of new CEO's. MIT Sloan Management Review, Winter: 14.

Bantel, K., \& Jackson, S. 1989. Top management and innovations in banking: Does the composition of the top team make a difference? Strategic Management Journal, 10: 107-124.

Barker, V.L., Patterson, P.W., \& Mueller, G.C. 2001. Organizational causes and strategic consequences of the extent of top management team replacement during turnaround attempts. Journal of Management Studies, 38: 235-269.

Beatty. R.P., \& Zajac, E.J. 1987. CEO change and firm performance in large corporations: Succession effects and manager effects. Strategic Management Journal, 8: 305-317.

Boeker, W. 1997. Strategic change: The influence of managerial characteristics and organizational growth. Academy of Management Journal, 40: 152-170.

Boeker, W. 1992. Power and managerial dismissal: scapegoating at the top. Administrative Science Quarterly, 27: 538-47.

Cannella, A.A., \& Monroe, M.J. 1997. Contrasting perspectives on strategic leaders: Toward a more realistic view of top managers. Journal of Management, 23: 213237.

Cannella, A.A., \& Hambrick, D.C. 1993. Effects of executive departures on the performance of acquired firms. Strategic Management Journal, 14: 137-152.

Cannella, A.A., \& Lubatkin, M. 1993. Succession as a sociopolitical process: Internal impediments to outsider selection. Academy of Management Journal, 36: 763793.

Chaganti, R., \& Sambharya, R. 1987. Strategic orientation and characteristics of uppper management. Strategic Management Journal, 8: 393-401

Child, J. 1972. Organizational structure, environment, and performance: The role of strategic choice. Sociology, 6: 1-22.

Corporate Board 2003. CEO turnover has hit a new high, 24.141:27-28.

Cyert, R.M. March, J.G. 1963. A behavioral theory of the firm. Englewood Cliffs: Prentice Hall.

Datta, D.K., \& Guthrie, J.P. 1994. Executive succession: Organizational antecedents of CEO characteristics. Strategic Management Journal, 15,:569-579.

DBM, 2002. Turnover at the top: research highlights from a global study. New York: Thomson-DBM.

Denis, D. J., Denis, D.K., \& Sarin, A. 1997. Ownership structure and top executive turnover. Journal of Financial Economics, 45: 193-221.

Denis, D.J., Denis, D.K. 1995. Performance changes following top management dismissals, Journal of Finance, L:4, 1029 - 1057. 
Finkelstein, S., \& Hambrick, D.C. 1996. Strategic leadership: top executives and their effects on organizations, New York: West.

Fizel, J.L., \& D'Itri, M.P. 1997. Managerial efficiency, managerial succession and organizational performance. Managerial and Decision Economics, 18: 295-308.

Friedman, S.D., \& Saul, K. 1991. A leader's wake: organization member reactions to CEO succession. Journal of Management, 17: 619-642.

Furtado, E.T.,\& Karan, V. 1990. Causes, consequences and shareholder wealth effects on management turnover: a review of the empirical evidence. Financial Management, 19: 60-75.

Gabarro, J.J. 1987. The dynamics of taking charge. Boston: Harvard Business School Press.

Gordon, S.S., Stewart, W.H., Sweo, R., \& Luker, W.A. 2000. Convergence versus strategic reorientation: the antecedents of fast-paced organizational change. Journal of Management, 26: 911-945.

Godthelp, M., \& Glunk, U. 2003. Turnover at the top: On the demographic determinants of executive turnover in the Netherlands. European Management Journal, 21, 614-626.

Goodstein, J.,Gautam, K., \& Boeker, W.1994. The effects of board size and diversity on strategic change. Strategic Management Journal, 15: 241-250.

Greene, W.H. 2003. Econometric analysis. Upper Saddle River: Prentice Hall.

Grusky, O. 1963. Managerial succession and organizational effectiveness. American Journal of Sociology, 69: 21-31

Grusky, O.1961. Corporate size, bureaucratization, and managerial succession. American Journal of Sociology, 67: 261-269.

Guthrie J.P., \& Datta, D.K. 1998. Corporate strategy, executive selection, and firm perfomance. Human Resource Management, 37: 101-116.

Hambrick, D.C., \& Cannella, A.A. Jr. 1993. Relative standing: a framework for understanding departures of acquired executives. Academy of Management Journal, 36:733-762.

Hambrick, D.C., Cho, T., \& Chen, M. 1996. The influence of top management team heterogeneity on firms' competitive moves. Administrative Science Quarterly, 41: 659-684.

Hambrick, D.C., \& D'Aveni, R. 1992. Top team deterioration as part of the downward spiral of large corporate bankruptcies. Management Science, 38: 1445-1466.

Hambrick, D.C., Geletkanycz, M., \& Frederickson, J. 1993. Top executive commitment to the status quo: A test of some of its determinants. Strategic Management Journal, 14: 410-418.

Hambrick, D.C., \& Mason, P.A. 1984. Upper echelons: the organization as a reflection of its top managers. Academy of Management Review, 9:193-206.

Hannan, M.T., \& Freeman, J.H. 1989. Organizational ecology. Cambridge,MA: Harvard University Press.

Hannan, M.T., \& Freeman, J.H.1984. Structural inertia and organizational change. American Sociological Review, 49: 149-164.

Hannan, M.T., \& Freeman, J.H.1977. The population ecology model of organizations. American Journal of Sociology, 82: 929-964. 
Huson, M.R., Parrino, R., \& Starks, L.T. 2001. Internal monitoring mechanisms and CEO turnover: a long-term perspective. Journal of Finance, 6: 2265-2297.

Iaquinto, A.L., \& Fredrickson, J.W. 1997. Top management agreement about the strategic decision process: A test of some of its determinants and consequences. Strategic Management Journal, 18: 63-75.

Jackson, S.E., Brett, J.F., Sessa, V.I., Cooper, D.M., Julin, J.A., \& Peyronnin, K. 1991. Some differences make a difference: individual dissimilarity and group heterogeneity as correlates of recruitment, promotions, and turnover. Journal of Applied Psychology, 76: 675-689.

Johnson, L.K. 2002. Do CEO's matter. MIT Sloan Management Review, Winter:8-9.

Kesner, I.F., \& Dalton, D.R. 1994. Top management turnover and CEO succession: an investigation of the effects of turnover on performance. Journal of Management Studies, 31: 701-713.

Kesner, I.F., \& Sebora, T.C. 1994. Executive succession: Past, present \& Future. Journal of Management, 20: 327-372.

Kirkman, B.L.\& Shapiro, D.L. 1997. The impact of cultural values on employee resistance to teams: Toward a model of globalized self-managing work team effectiveness. Academy of Management Review, 22: 730-757.

Kotter, J.P. 1982. The general managers. New York: Free Press.

Krishnan, H.A., Miller, A., \& Judge, W.Q.1997. Diversification and top management team complementarity: is performance improved by merging similar or dissimilar teams?. Strategic Management Journal, 18: 361-374.

Leonard, B. 2001. Turnover at the top. HR Magazine, May: 46-52.

Leker, J., \& Salomo, S. 2000. CEO turnover and corporate performance. Scandinavian Journal of Management, 16: 287-303.

Lubatkin, M.H., Chung, K.H., Rogers, R.C., \& Owens, J.E. 1989. Stockholder reactions to CEO changes in large corporations. Academy of Management Journal, 32: 4768.

Meindl, J.R., Ehrlich, S.B., \& Dukerich, J.M. 1985. The romance of leadership. Administrative Science Quarterly, 30: 78-102.

Michel, J.G., \& Hambrick, D.C. 1992. Diversification posture and top management team characteristics. Academy of Management Journal, 35: 9-37.

Miller, D.1993. Some organizational consequences of CEO succession. Academy of Management Journal, 36: 644-659.

Miller, D.1991. Stale in the saddle: CEO tenure and the match between organization and environment. Management Science, 37: 34-52.

Nelson, R., \& Winter, S. 1982. An evolutionary theory of economic change. Cambridge: Harvard University Press.

Nystrom, P.C., \& Starbuck, W.H. 1984. To avoid organizational crises - unlearn. Organizational Dynamics, 12: 53-65.

Olie, R.L., \& Van Iterson, A. 2003. Top management teams in their national context. In Cheng, J., \& Hitt. M. (Eds). Advances in International Management: Managing multinationals in a knowledge economy; Economics, culture and human resources. Greenwich: Jai Press.

Pfeffer, J. 1982. Organizations and Organization Theory. Boston: Pitman. 
Pfeffer, J. 1981. Management as symbolic action: the creation and maintenance of organizational paradigms. In: Cummings, L.L., \& Staw, B.M. (Eds). Research in Organizational Behavior, Greenwich: Jai Press: 1-52.

Pfeffer, J.1977. The ambiguity of leadership. Academy of Management Review, 2: 104112.

Puffer, S.M., \& Weintrop, J.B. 1991. Corporate performance and CEO turnover: the role of performance expectations. Administrative Science Quarterly, 36: 1-19.

Shen, W., \& Cannella, A.A. Jr.2003. Will succession planning increase shareholder wealth? Evidence from investor reactions to relay CEO successions. Strategic Management Journal, 24: 191-198.

Shen, W., \& Cannella, A.A. Jr.2002. Revisiting the performance consequences of CEO succession: the impacts of successor type, postsuccession senior executive turnover, and departing CEO tenure. Academy of Management Journal, 45: 717733.

Schneider, B. 1987. The people make the place. Personnel Psychology, 40: 437-453.

Tushman, M.L., \& Rosenkopf, L. 1996. Executive succession, strategic reorientation and performance growth: a longitudinal study in the US Cement Industry. Management Science, 42: 939-953.

Tushman, M.L., \& Romanelli, E. 1985. Organizational evolution: a metomorphosis model of convergence and reorientation. Research in Organizational Behavior, 7:171-222.

Tushman, M.L., Virany, B., \& Romanelli, E. 1985. Executive succession, strategic reorientation, and organizational evolution. Technology in Society, 7: 297-314.

Vancil, R.F. 1987. Passing the baton. Boston: Harvard Business School Press.

Virany, B., Tushman, M.L., \& Romanelli, E. 1992. Executive succession and organization outcomes in turbulent environments: an organization learning approach. Organization Science, 3: 72-91.

Wagner, W.G. Pfeffer, J., \& O’Reilly, C.A. 1984. Organizational demography and turnover in top management groups. Administrative Science Quarterly, 29: 7492.

Walsh, J.P. 1988. Top management turnover following mergers and acquisitions. Strategic Management Journal, 9:173-184.

Walsh, J.P. 1989. Doing a deal: Merger and acquisition negotiations and their impact upon target company top management turnover. Strategic Management Journal, 10: 307-322.

Wiersema, M.F., \& Bantel, K.A. 1993. Top management turnover as an adaptation: the role of the environment. Strategic Management Journal, 14: 485-504.

Wiersema, M.F., \& Bantel, K.A. 1992. Top management demography and corporate strategic change. Academy of Management Journal, 35:91-121.

Zajac, E.J. 1990. CEO selection, succession, compensation, and firm performance: a theoretical integration and empirical analysis. Strategic Management Journal, 11:313-330.

Zhang, Y., \& Rajagopalan, N. 2003. Explaining new CEO origin: Firm versus industry antecedents. Academy of Management Journal, 46: 327-338. 
Antecedent conditions

\begin{tabular}{|l|}
\hline FOR EXAMPLE: \\
Financial-economic focus \\
(e.g. Huson, Parrino and \\
Starks, 2001; Allgood and \\
Farrell, 2000; Furtado and \\
Karan, 1990) \\
Mergers and acquisitions \\
(e.g. Krishnan, Miller and \\
Judge, 1997; Canella and \\
Hambrick, 1993; Walsh, \\
1988,1989) \\
Demographic dissimiliarity \\
(e.g. Finkelstein and \\
Hambrick 1996; Jackson \\
et. al, 1991; Wagner, \\
Pfeffer and O'Reilly, 1984) \\
\hline
\end{tabular}

FOR EXAMPLE:
CEO succession
(e.g., Beatty and Zajac, 1987;
Lubatkin, Chung, Rogers and
Owers, 1989; Leker and Salomo,
2000)
CEO versus other members of the
top team (e.g. Shen and Cannella,
2002; Tushman and Rosenkopf,
1996; Virany, Tushman and
Romanelli, 1992)
CEO entries ( and team changes)
(e.g. Beatty and Zajac, 1987;
Lubatkin, Chung, Rogers and
Owers, 1989; Zajac, Kesner and
Dalton, 1994; Shen and Cannella,
2002; Virany et al, 1992; Boeker,
1997)
CEO exits (and team changes)
(e.g, Shen and Cannella, 2002;
Kesner and Dalton, 1994; Boeker,
1997)
Team changes
(Boeker, 1997; Barker, Patterson
and Mueller, 2001)
Frequency of CEO (and team
changes)
(e.g., Grusky, 1961; Miller, 1991;
Virany et al., 1992; Hambrick and
d'Aveni, 1992)

\section{Intermediate} (team) processes

\section{FOR EXAMPLE:}

Firm specific knowledge (e.g. Shen and Cannella, 2002)

Change initiatives (Miller, 1991; Boeker, 1997)

Risk of adverse selection (Zajac, 1990; Shen and

Cannella, 2002)

Social cohesion

(Hambrick and D'Aveni, 1992)

Resource diversity (Boeker, 1997;

Hambrick and D'Aveni, 1992)

\section{FOR EXAMPLE:}

Strategic or organizational change

(e.g. Boeker 1997, 1992;

Miller, 1993)

Organizational effectiveness (e.g. Miller, 1991; Grusky, 1963)

Shareholder reactions (e.g. Beatty and Zajac, 1987; Lubatkin, Chung, Rogers and Owers, 1989)

Financial performance (e.g. Shen and Cannella, 2002; Virany, Tushman and Romanelli, 1992) 


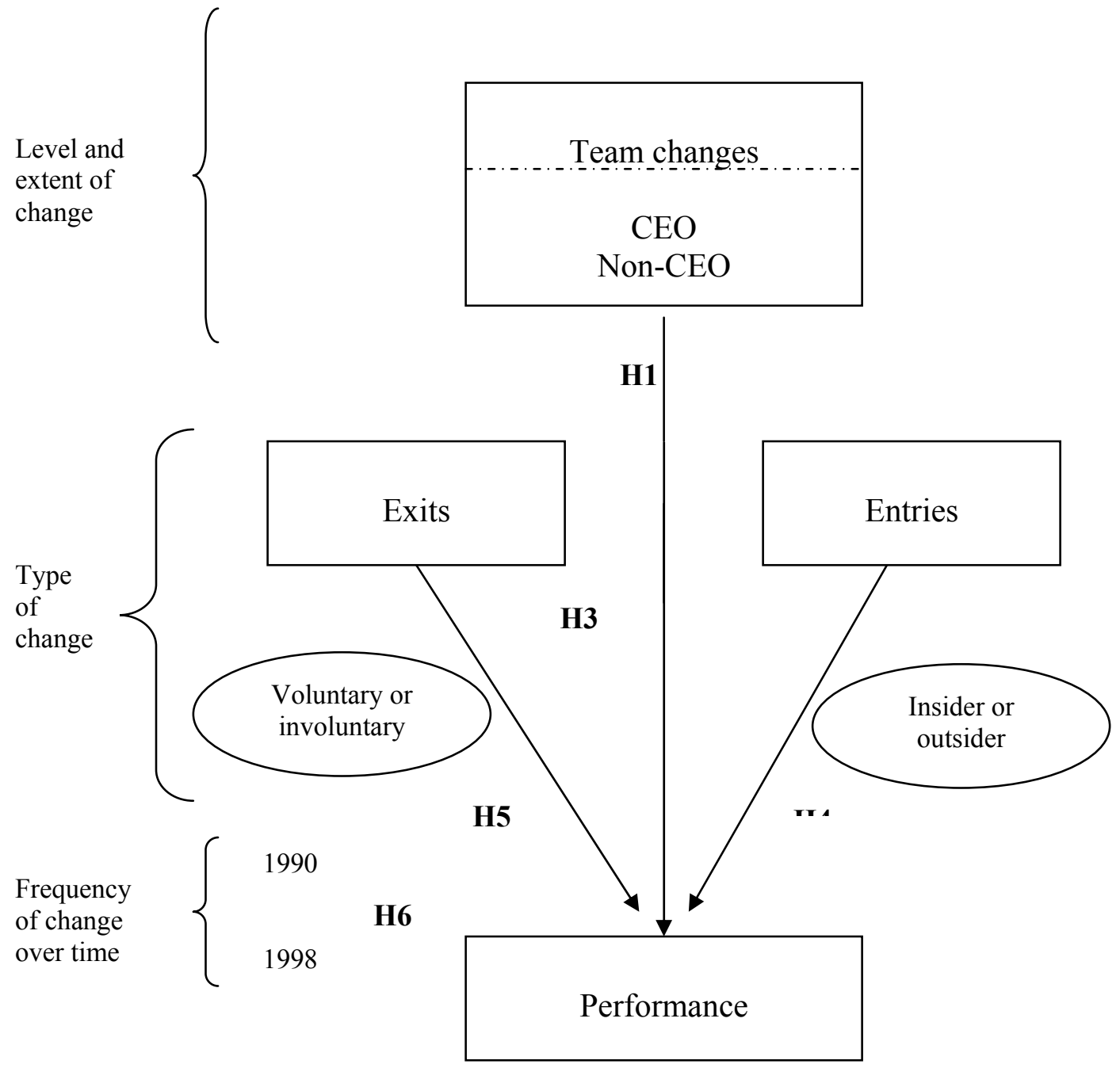

Figure 2: Research model 
Table 1: Means, standard deviations and correlations

\begin{tabular}{|c|c|c|c|c|c|c|c|c|c|c|c|c|c|c|}
\hline & Mean & SD & 1. & 2. & 3. & 4. & 5. & 6. & 7. & 8. & 9. & 10. & 11. & 12. \\
\hline 1. Sector & 0.55 & 0.49 & 1.0 & & & & & & & & & & & \\
\hline 2. Net sales $(\ln )$ & 14.45 & 1.20 & $-.23 * * *$ & 1.0 & & & & & & & & & & \\
\hline 3. Prior ROA change & 0.04 & 4.03 & .02 & -.03 & 1.0 & & & & & & & & & \\
\hline 4. CEO change & 0.14 & 0.35 & -.02 & $.13 * *$ & -.09 & 1.0 & & & & & & & & \\
\hline 5. Non-CEO change prop. & 0.20 & 0.30 & -.05 & $.23 * * *$ & -.08 & .06 & 1.0 & & & & & & & \\
\hline 6. TMT change proportion & 0.23 & 0.34 & .04 & $.15 * * *$ & $-.15 * *$ & $.44 * * *$ & $.68 * * *$ & 1.0 & & & & & & \\
\hline 7. TMT exit proportion & 0.10 & 0.18 & .04 & $.17 * * *$ & $-.15 * *$ & $.43 * * *$ & $.50 * * *$ & $.72 * * *$ & 1.0 & & & & & \\
\hline 8. TMT entry proportion & 0.13 & 0.24 & .03 & $.10^{*}$ & $-.10^{*}$ & $.30 * * *$ & $.58 * * *$ & $.86^{* * *}$ & $.27 * * *$ & 1.0 & & & & \\
\hline 9. Outside entries & 0.26 & 0.44 & .07 & .04 & .10 & -.09 & .02 & $-.10 *$ & .02 & $-.14^{*}$ & 1.0 & & & \\
\hline 10.Retirement exits & 0.44 & 0.49 & .11 & .05 & .01 & .05 & $-.19 *$ & $-.19 *$ & $-.30 * *$ & -.09 & -.06 & 1.0 & & \\
\hline 11. ROA change $\mathrm{t} 1-\mathrm{t} 0$ & 0.21 & 4.45 & .01 & -.05 & $-.12 *$ & .05 & .02 & .08 & $.16^{* * *}$ & .01 & -.03 & -.12 & 1.0 & \\
\hline 12. ROA change $\mathrm{t} 2-\mathrm{t} 0$ & 0.30 & 5.36 & .05 & -.07 & $-.15^{*}$ & .04 & .04 & .05 & $.12 *$ & -.01 & -.03 & -.12 & $.60 * * *$ & 1.0 \\
\hline 13. ROA change $\mathrm{t} 3-\mathrm{t} 0$ & 0.56 & 5.29 & .03 & .03 & $-.15^{*}$ & -.00 & .06 & .07 & .04 & .07 & -.02 & -.17 & $.37 * * *$ & $.61 * * *$ \\
\hline
\end{tabular}

TMT: top management team; ${ }^{*} \mathrm{p} \leq .05, * * \mathrm{p} \leq .01, * * * \mathrm{p} \leq .001$ 
Table 2: Level and extent of change

\begin{tabular}{|c|c|c|c|c|c|c|c|c|c|}
\hline \multirow{3}{*}{ Variables } & Model 1 & Model 2 & Model 3 & Model 4 & Model 5 & Model 6 & Model 7 & Model 8 & Model 9 \\
\hline & $\mathrm{ROA}$ & ROA & ROA & ROA & ROA & ROA & ROA & ROA & ROA \\
\hline & change t1 & change $\mathrm{t} 2$ & change $\mathrm{t} 3$ & change $\mathrm{t} 1$ & change $\mathrm{t} 2$ & change $\mathrm{t} 3$ & change t1 & change $\mathrm{t} 2$ & change $\mathrm{t} 3$ \\
\hline Sector & .01 & .26 & .42 & .01 & .22 & .38 & -.00 & .27 & .44 \\
\hline Net sales (ln) & -.19 & -.24 & .14 & -.19 & -.27 & .13 & -.19 & -.24 & .16 \\
\hline Non-CEO change & .90 & .62 & 1.79 & 1.04 & -.22 & 1.15 & & & \\
\hline proportion & & & & & & & & & \\
\hline CEO change times & & & & -.88 & 6.93 & 5.30 & & & \\
\hline Wald Chi2 & 6.69 & 8.09 & 8.09 & 6.79 & 11.64 & 9.53 & 6.75 & 8.33 & 8.06 \\
\hline $\mathrm{R}^{2}$ overall & 0.02 & 0.03 & 0.03 & 0.02 & 0.04 & 0.03 & 0.02 & 0.03 & 0.03 \\
\hline
\end{tabular}

TMT: top management team; values are regression coefficients; ${ }^{*} \mathrm{p} \leq .05,{ }^{*} \mathrm{p} \leq .01,{ }^{* * *} \mathrm{p} \leq .001$. 
Table 3: Type of change: exits vs. entries

\begin{tabular}{|c|c|c|c|c|c|c|}
\hline Variables & $\begin{array}{c}\text { Model } 1 \\
\text { ROA } \\
\text { change t1 }\end{array}$ & $\begin{array}{c}\text { Model } 2 \\
\text { ROA } \\
\text { change t2 }\end{array}$ & $\begin{array}{c}\text { Model } 3 \\
\text { ROA } \\
\text { change t3 }\end{array}$ & $\begin{array}{c}\text { Model } 4 \\
\text { ROA } \\
\text { change t1 }\end{array}$ & $\begin{array}{c}\text { Model } 5 \\
\text { ROA } \\
\text { change t2 }\end{array}$ & $\begin{array}{c}\text { Model } 6 \\
\text { ROA } \\
\text { change t3 }\end{array}$ \\
\hline Sector & .07 & .31 & .41 & .10 & .31 & .48 \\
\hline Net sales $(\ln )$ & -.22 & -.26 & .16 & -.18 & -.26 & .17 \\
\hline Prior ROA change & -.12 & $-.22 *$ & $-.22 *$ & -.11 & $-.21 *$ & $-.23 *$ \\
\hline CEO change & -.66 & -.67 & -.88 & -.58 & -.67 & -1.06 \\
\hline $\begin{array}{l}\text { TMT exit } \\
\text { Proportion }\end{array}$ & $5.81 * *$ & $5.57 *$ & -.18 & .72 & 6.37 & -2.65 \\
\hline $\begin{array}{l}\text { TMT entry } \\
\text { Proportion }\end{array}$ & -.86 & -.85 & 2.43 & $-2.72 *$ & -.48 & 1.39 \\
\hline $\begin{array}{l}\text { TMT exit times } \\
\text { entry proportion }\end{array}$ & & & & $17.79 * * *$ & 13.35 & 13.00 \\
\hline Wald Chi2 & $15.64 *$ & 12.28 & 8.56 & $26.76^{* * *}$ & 12.28 & 10.17 \\
\hline $\mathrm{R}^{2}$ overall & 0.04 & 0.04 & 0.03 & 0.08 & 0.04 & 0.04 \\
\hline
\end{tabular}


Table 4: Type of exits and entries

\begin{tabular}{|c|c|c|c|c|c|c|}
\hline Variables & $\begin{array}{c}\text { Model 1 } \\
\text { ROA } \\
\text { change t1 }\end{array}$ & $\begin{array}{c}\text { Model } 2 \\
\text { ROA } \\
\text { change t2 }\end{array}$ & $\begin{array}{c}\text { Model } 3 \\
\text { ROA } \\
\text { change t3 }\end{array}$ & $\begin{array}{c}\text { Model } 4 \\
\text { ROA } \\
\text { change t1 }\end{array}$ & $\begin{array}{c}\text { Model } 5 \\
\text { ROA } \\
\text { change t2 }\end{array}$ & $\begin{array}{c}\text { Model } 6 \\
\text { ROA } \\
\text { change t3 }\end{array}$ \\
\hline Sector & .06 & .32 & .39 & .19 & .34 & .47 \\
\hline Net sales $(\ln )$ t0 & -.34 & -.23 & .15 & -.09 & -.30 & .24 \\
\hline Prior ROA change & -.12 & $-.22 *$ & $-.22 *$ & $-.14^{*}$ & $-.21 *$ & $-.21 *$ \\
\hline CEO change & -.29 & -.71 & -.79 & -.48 & .15 & .84 \\
\hline $\begin{array}{l}\text { TMT exit } \\
\text { proportion }\end{array}$ & $4.84 * *$ & $5.66^{*}$ & -.43 & $6.74 *$ & $7.91 *$ & -.69 \\
\hline $\begin{array}{l}\text { TMT entry } \\
\text { proportion }\end{array}$ & -.04 & -.96 & 2.15 & -1.39 & -1.08 & 1.47 \\
\hline Outsider & $4.99^{* * *}$ & -.70 & .57 & & & \\
\hline $\begin{array}{l}\text { Outsider times } \\
\text { TMT entry prop. }\end{array}$ & $-14.47 * * *$ & 2.03 & .09 & & & \\
\hline Retirement & & & & $-3.66^{*}$ & -.33 & -2.41 \\
\hline $\begin{array}{l}\text { Retirement times } \\
\text { TMT exit prop. }\end{array}$ & & & & 8.25 & -4.16 & 2.03 \\
\hline Wald Chi2 & $29.91 * * *$ & 12.31 & 8.73 & $18.40^{*}$ & 12.19 & 7.51 \\
\hline $\mathrm{R}^{2}$ overall & 0.08 & 0.04 & 0.04 & 0.06 & 0.04 & 0.03 \\
\hline
\end{tabular}

TMT: top management team; values are regression coefficients; ${ }^{*} \mathrm{p} \leq .05,{ }^{* *} \mathrm{p} \leq .01,{ }^{* * *} \mathrm{p} \leq .001$. 
Table 5: Means, standard deviations and correlations

\begin{tabular}{|c|c|c|c|c|c|c|c|c|}
\hline & Mean & SD & 1. & 2. & 3. & 4. & 5. & 6. \\
\hline 1. Sector & 0.55 & 0.50 & 1.0 & & & & & \\
\hline 2. Average net sales (ln) $1990-1998$ & 14.32 & 1.14 & -.24 & 1.0 & & & & \\
\hline $\begin{array}{l}\text { 3. No. of years with TMT changes } \\
\text { 1990-1998 }\end{array}$ & 3.98 & 2.04 & -.12 & $.41^{* *}$ & 1.0 & & & \\
\hline $\begin{array}{l}\text { 4. No. of years with CEO changes } \\
\text { 1990-1998 }\end{array}$ & 1.08 & 0.92 & -.11 & $.34 *$ & $.41 * *$ & 1.0 & & \\
\hline $\begin{array}{l}\text { 5. No. of years with non-CEO } \\
\text { changes 1990-1998 }\end{array}$ & 1.97 & 1.67 & -.13 & $.48 * * *$ & $.93 * * *$ & .18 & 1.0 & \\
\hline 6. Average ROA 1999-2000 & 9.20 & 4.76 & .16 & $-.52 * * *$ & $-.29 \dagger$ & $-.40 * *$ & -.22 & 1.0 \\
\hline
\end{tabular}

Table 6: Frequency of changes over time

\begin{tabular}{|c|c|c|c|c|}
\hline Variables & Model 1 & Model 2 & Model 3 & Model 4 \\
\hline Sector & .04 & .02 & .03 & .04 \\
\hline Net sales $(\ln )$ 1990-1988 & $-.46 * *$ & $-.50 * *$ & $-.43 * *$ & $-.53 * *$ \\
\hline $\begin{array}{l}\text { No. of years with TMT } \\
\text { changes 1990-1998 }\end{array}$ & -.09 & -.56 & & \\
\hline $\begin{array}{l}\text { Squared no. of years with } \\
\text { TMT changes 1990-1998 }\end{array}$ & & .50 & & \\
\hline $\begin{array}{l}\text { No. of years with CEO } \\
\text { changes } 1990-1998\end{array}$ & & & $-.26 \dagger$ & \\
\hline $\begin{array}{l}\text { No. of years with non-CEO } \\
\text { changes 1990-1998 }\end{array}$ & & & & .03 \\
\hline $\mathrm{R}^{2}$ & $.27^{* *}$ & $.30^{* *}$ & $.33 * * *$ & $.27 * * *$ \\
\hline
\end{tabular}

